\title{
Churg-Strauss syndrome associated with antiphospholipid antibodies in a patient with recurrent myocardial and cerebral ischemia
}

This article was published in the following Dove Press journal:

International Medical Case Reports Journal

31 October 2012

Number of times this article has been viewed

\author{
Marino Paroli' \\ Alessandro Polidoro' \\ Simone Romano' \\ Daniele Accapezzato ${ }^{2}$ \\ 'Department of Biotechnology \\ and Medical-Surgical Sciences, \\ ${ }^{2}$ Department of Internal Medicine \\ and Medical Specialties, Sapienza \\ University of Rome, Rome, Italy
}

Correspondence: Marino Paroli Sapienza University of Rome, Piazzale Aldo Moro 5, 0016I Roma, Italy

$\mathrm{Tel}+390773476814$

Fax +390773476813

Email marino.paroli@uniromal.it

\begin{abstract}
We report on a case of Churg-Strauss syndrome (CSS) associated with the presence of antiphospholipid antibodies. The patient had a history of recurrent myocardial infarction and presented with acute ischemic cerebral disease. Eosinophilia with typical lung and skin lesions led us to diagnose the patient with CCS. We hypothesize that the presence of antiphospholipid antibodies significantly contributed to the ischemic events. We suggest that the search for antiphospholipid antibodies should be included in the laboratory work-up in CSS patients and patients affected by primary systemic vasculitides in general. Moreover, anticoagulant treatment appears to be warranted in all CSS patients and antiphospholipid antibodies to counteract this thrombosis-favoring association.
\end{abstract}

Keywords: Churg-Strauss syndrome, antiphospholipid antibodies, ischemic disease

\section{Introduction}

Churg-Strauss syndrome (CSS) is a medium-small vasculitis included in the antineutrophil cytoplasmic antibodies (ANCA)-associated vasculitis (AAV). CCS is associated in $40 \%$ of cases with perinuclear-ANCA-recognizing myeloperoxidase (MPO) antigen, whereas the remaining cases are ANCA-negative. This vasculitis progresses through three phases: the first is characterized by allergy-like symptoms including severe asthma and peripheral eosinophilia; the second in which tissues are infiltrated by eosinophils; and the third in which frank vasculitis develops. ${ }^{1}$ In this report, we describe a case of CSS associated with the presence of antiphospholipid antibodies and presenting with recurrent ischemic myocardial and cerebral disease.

\section{Case report}

A 46-year-old Caucasian woman was admitted to our department in 2011 for the sudden onset of motor and sensitive neurologic deficit in the right both upper and lower limbs. The patient had no history of hypertension, diabetes mellitus, valvular heart disease, or atherosclerosis. Her past medical history revealed the presence of severe asthma since the age of 18 years with allergometric tests for inhalants and food allergens showing negative results. She was under treatment with inhaled corticosteroids and with $\beta_{2}$-agonists. She had also a history of erythema nodosum and two episodes of recurrent myocardial infarction; the first one in 1994 (non-ST-segment elevated myocardial infarction) and the second one in 2004 (ST-segment elevated myocardial infarction). At that time, angiographic investigation did not reveal any atherosclerotic plaque within the coronary arteries. Treatment with acetylsalicylic acid daily was then begun. 
On examination, the patient had motor and sensitive deficit involving right both upper and lower extremities. In addition, the patient complained of mastitis of the right breast, which was present from about 3 months before and was treated unsuccessfully with antibiotics.

Laboratory findings showed a slightly elevated white blood cell count of $13.0 \times 10^{9} / \mathrm{L}$, an elevated absolute eosinophil count of $8.64 \times 10^{9} / \mathrm{L}$, elevated rheumatoid factor $126 \mathrm{IU} / \mathrm{mL}$, reference range ( $0-15 \mathrm{IU} / \mathrm{mL})$, elevated immunoglobulin E (IgE; $324 \mathrm{IU} / \mathrm{mL}$ ), erythrocyte sedimentation rate $65 \mathrm{~mm} /$ hour, and $\mathrm{C}$ reactive protein of $2.23 \mathrm{mg} / \mathrm{dL}$ (reference range $0.00-0.50 \mathrm{mg} / \mathrm{dL}$ ). The patient had negative cytoplasmic-ANCA, perinuclear-ANCA, ANA, and cryoglobulins. Antihepatitis C virus, hepatitis B surface antigen and anti-human immunodeficiency virus were also negative. Anti- $\beta_{2}$ glycoprotein I antibodies (anti- $\beta_{2}$ GPI) (IgM) were positive (56 GPI units). These were repeatedly positive (62 GPI units) 12 weeks after the first determination.

Chest high-resolution computed tomography revealed bilateral nonsegmental consolidation due to interstitial thickening (Figure 1). Pulmonary infiltrates revealed to be nonfixed in sequential chest X-ray images. Cerebral magnetic resonance imaging (MRI) showed the presence of a left thalamic ischemic lesion (Figure 2). Liver, spleen, and kidney ultrasound were negative. An echocardiogram revealed a significant deficit in heart contractility with an ejection fraction of $48 \%$. A skin biopsy of the breast revealed extensive areas occupied by periductal necrotizing granulomas and an inflammatory infiltrate constituted mainly by eosinophils. Injury of medium and small vessels was also present. Both periodic acid-Schiff and Ziehl-Neelsen staining excluded the presence of pathogens within the lesion. These results were compatible with a diagnosis of CSS. The patient now fulfilled the criteria for CSS as established by the American College of Rheumatology. ${ }^{2}$

After the diagnosis of CSS was made, 3 days of intravenous pulse-dose corticosteroids were administered and followed by oral treatment with $50 \mathrm{mg}$ prednisone and $100 \mathrm{mg}$ cyclophosphamide daily. Anticoagulation with warfarin was added to the regimen. Asthma and motor and sensitive deficits progressively improved. The patient is presently followed up at our institution by a multidisciplinary clinical team.

\section{Discussion}

CSS in a medium-small vessel vasculitis is classified as an AAV. The pathogenesis of CSS is still unknown. ANCA play a pathogenetic role in $\mathrm{AAV}^{3}$ However, perinuclear-ANCA

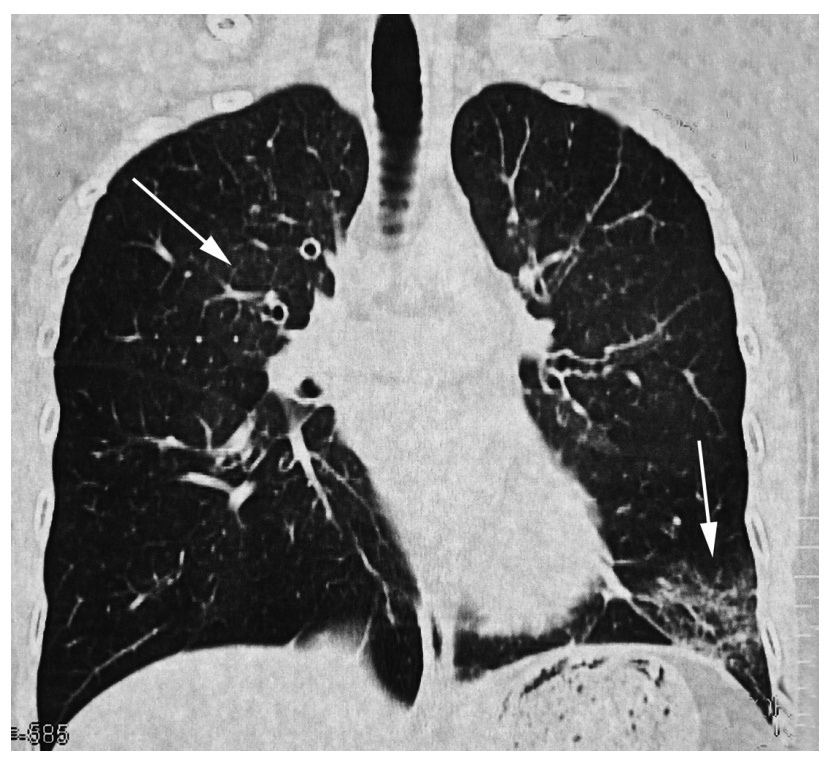

Figure I Chest high-resolution computed tomography.

Note: Images of interstitial disease are visible in the right medial segments and in the left basal area of the lung (white arrows).

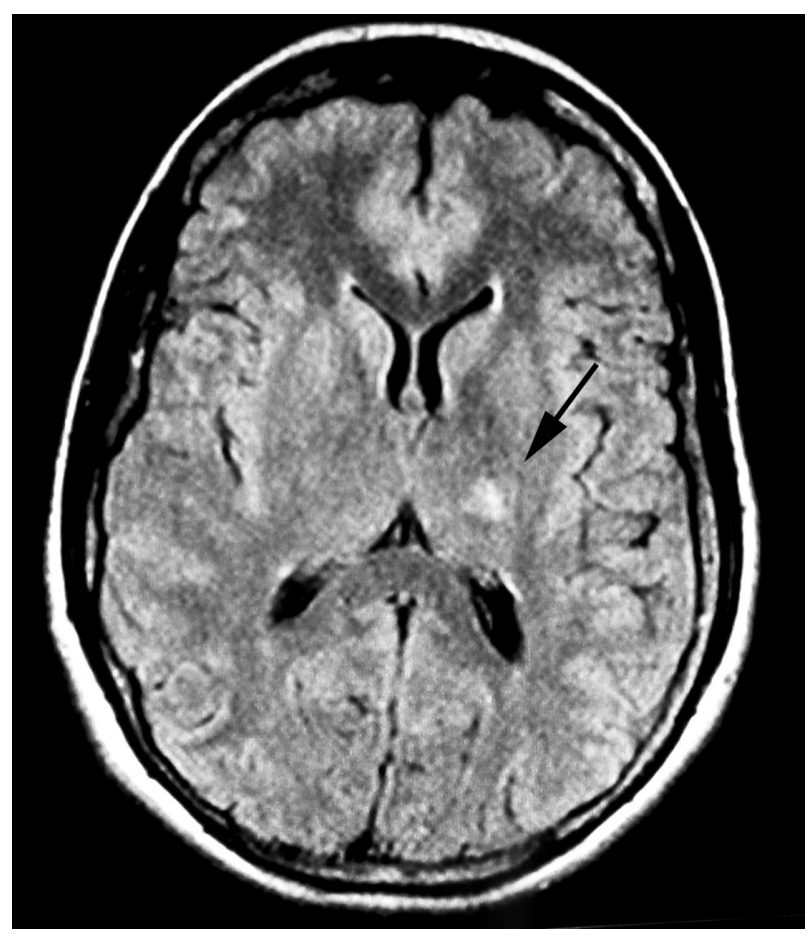

Figure 2 Cerebral magnetic resonance imaging.

Note: $T_{1}$-weighted sequence after infusion of contrast agent shows a left thalamic hyperintense signal due to subacute ischemic lesion (black arrow).

are present in only $40 \%$ of CSS patients. Therefore, other factors are likely to be responsible for the pathogenesis of the disease. These include abnormal cell apoptosis inducing T-cell response by a mechanism of cross-presentation ${ }^{4}$ as recently demonstrated in other autoimmune conditions. ${ }^{5}$ 
Moreover, the cytokine network, in particular interleukin-6 (IL-6) may induce rheumatoid factor formation and induce vasculitis. ${ }^{6}$ Interestingly, IL-6 is also important in heart damage, ${ }^{7}$ and this could explain in part the recurrent myocardial infarction in our patient. On the other hand, both apoptosis ${ }^{8}$ and IL- $6^{9}$ are involved in antiphospholipid syndrome. Ischemic heart disease ${ }^{10}$ and stroke ${ }^{11}$ are both described in CSS. Therefore, the patient was already at risk for premature atherosclerotic disease due to atheroma formation favored by chronic inflammation or to vasculitis as well. In addition, eosinophil cationic protein, myelin basic protein, and eosinophil peroxidase, which are all contained in eosinophil granules, can induce a hypercoagulable state. ${ }^{12}$ However, the high rate of recurrence of ischemic events leads us to suspect a possible additional risk factor for arterial ischemia. Although it is not possible to establish the relative role of CSS-associated vasculitis or thrombosis in cardiac and brain ischemia in our patient as discussed above, we think that warfarin therapy should be instituted when antiphospholipid antibodies are also present. In addition, we believe that antiphospholipid antibodies should be identified in all these patients. Very few similar cases have been reported so far. In a report from Acciarini et al, ${ }^{13}$ a case of thrombosis of the right retinic vein associated with anticardiolipin antibodies in a patient with CSS has been observed. Rees et al described two cases of CCS who presented with thrombotic cardiovascular accidents and positivity for antiphospholipid antibodies. ${ }^{14}$ Ferenczi et $\mathrm{al}^{15}$ reported a case of CSS characterized by severe digital gangrene in the presence of antiphospholipid antibodies. Interestingly, the presence of antiphospholipid antibodies has also been reported in other AAV including Wegener's disease. ${ }^{16}$ Further study is therefore needed to establish the prevalence of the association between CCS (or other AAV) and antiphospholipid antibodies, and to better define the optimal antithrombotic therapy for these patients.

\section{Disclosure}

The authors report no conflict of interest in this work

\section{References}

1. Abril A. Churg-Strauss syndrome: an update. Curr Rheumatol Rep. 2011;13(6):489-495.

2. Masi AT, Hunder GG, Lie JT, et al. The American College of Rheumatology 1990 criteria for the classification of Churg-Strauss syndrome (allergic granulomatosis and angiitis). Arthritis Rheum. 1990;33(8):1094-1100.

3. van Timmeren MM, Heeringa P. Pathogenesis of ANCA-associated vasculitis: recent insights from animal models. Curr Opin Rheumatol. 2012;24(1):8-14.

4. Chen M, Kallenberg CG. The environment, geoepidemiology and ANCA-associated vasculitides. Autoimmun Rev. 2010;9(5): A293-A298.

5. Franceschini D, Del Porto P, Piconese S, et al. Polyfunctional type-1, -2 , and $-17 \mathrm{CD} 8(+) \mathrm{T}$ cell responses to apoptotic self-antigens correlate with the chronic evolution of hepatitis C virus infection. PLoS Pathog. 2012;8(6):e1002759.

6. Yokoyama A, Kohno N, Fujino S, Inoue Y, Hiwada K. IgG and IgM rheumatoid factor levels parallel interleukin-6 during the vasculitic phase in a patient with Churg-Strauss syndrome. Intern Med. 1995;34(7):646-648.

7. Sardella G, Mariani P, D'Alessandro M, et al. Early elevation of interleukin-1beta and interleukin-6 levels after bare or drug-eluting stent implantation in patients with stable angina. Thromb Res. 2006;117(6):659-664.

8. Alessandri C, Conti F, Pendolino M, Mancini R, Valesini G. New autoantigens in the antiphospholipid syndrome. Autoimmun Rev. 2011;10(10):609-616.

9. Arslan E, Colakoglu M, Celik C, et al. Serum TNF-alpha, IL-6, lupus anticoagulant and anticardiolipin antibody in women with and without a past history of recurrent miscarriage. Arch Gynecol Obstet. 2004;270(4):227-229.

10. Courand PY, Croisille P, Khouatra C, Cottin V, Kirkorian G, Bonnefoy E. Churg-Strauss syndrome presenting with acute myocarditis and cardiogenic shock. Heart Lung Circ. 2012;21(3):178-181.

11. Kang DW, Kim DE, Yoon BW, Seo JW, Roh JK. Delayed diagnosis: recurrent cerebral infarction associated with Churg-Strauss syndrome. Cerebrovasc Dis. 2001;12(3):280-281.

12. Taki H, Shinoda K, Hounoki H, et al. Serum interleukin-5 levels correlate with disease activity of Churg-Strauss syndrome in a patient treated with a leucotriene receptor antagonist, pranlukast, and inhaled corticosteroid. Scand J Rheumatol. 2010;39(4):341-343.

13. Acciarini AE, Rubino S, Biscarini L, Del FA. Churg-Strauss syndrome or other disease? Clin Exp Rheumatol. 2002;20(1):116; author reply 116-117.

14. Rees JD, Lanca S, Marques PV, et al. Prevalence of the antiphospholipid syndrome in primary systemic vasculitis. Ann Rheum Dis. 2006;65(1):109-111.

15. Ferenczi K, Chang T, Camouse M, et al. A case of Churg-Strauss syndrome associated with antiphospholipid antibodies. J Am Acad Dermatol. 2007;56(4):701-704.

16. Paul SN, Sangle SR, Bennett AN, et al. Vasculitis, antiphospholipid antibodies, and renal artery stenosis. Ann Rheum Dis. 2005;64(12): 1800-1802.
International Medical Case Reports Journal

\section{Publish your work in this journal}

The International Medical Case Reports Journal is an international, peer-reviewed open-access journal publishing original case reports from all medical specialties. Previously unpublished medical posters are also accepted relating to any area of clinical or preclinical science. Submissions should not normally exceed 2,000 words or

\section{Dovepress}

4 published pages including figures, diagrams and references. The manuscript management system is completely online and includes a very quick and fair peer-review system, which is all easy to use. Visit http://www.dovepress.com/testimonials.php to read real quotes from published authors. 